\title{
OBITUARY
}

\section{Alan Bentley Monro}

Dr 'Ben' Monro died suddenly on 30 May, aged 68 years. He had been a Lord Chancellor's Medical Visitor since 1973. Previously his career had been in psychiatric hospitals and he became a distinguished Medical Superintendent of Long Grove Hospital, Epsom. He was early to introduce there 'Industrial Therapy' and elsewhere to develop a 'Day Hospital'. Again, when the first Adolescent Unit was transferred from St. Ebba's Hospital to Long Grove he at once took an active personal part in the practice of adolescent psychiatry. His few writings reflected his earlier interest in statistical analysis.

Ben Monro was best known to British psychiatrists for his outstanding work for the Royal MedicoPsychological Association. Joint Secretary to the Parliamentary Committee in 1956-7, he was the obvious choice to became General Secretary, and he held this office from 1957 to 1971 with very great distinction. Presidents changed each year then, and so he carried considerable responsibility for the affairs of the Association. His tall and impressive presence dignified all meetings, while he carried out his wide-ranging duties with quiet efficiency and courtesy. Nevertheless, he could show great firmness if necessary. All of us depended much on his experience, wisdom and judgement. His contribution to the Association and then to the College to be, although unobtrusive, was of crucial importance. He coped with any difficulties that arose, and he was the main drafter of the College Bye-Laws and Regulations. He had the gift of lucidity and with it the ability to write important memoranda at speed.

He was a member of many important committees both inside and outside the Association, and his influence was wide. He was at the hub throughout the period leading up to the formation of the new Royal College of Psychiatrists, and his loyalty and hard work throughout were paramount. Much was therefore owed him and he was elected an Honorary Fellow in 1973 .

Socially, he was a kindly friend, always ready to help anyone; and his dry wit was enjoyable. Devoted to his wife, family and home, they equally supported him.

W.W.

\section{MENTAL HANDIGAP: A REPLY FROM THE DHSS}

A copy of the College's Memorandum on Mental Handicap (Bulletin, April 1978, p 56), was sent to the DHSS, and the following reply has now been received:

In general the Department welcomes the spirit of this Memorandum which outlines clearly the role of psychiatrists in a comprehensive range of services for the mentally handicapped. No doubt you will now have seen our circular on the Court Report $\mathrm{HC}(78) 5$ including the section on child psychiatry services which takes account of the College's earlier comments.

The Memorandum's manpower proposals seem to be very helpful and we will certainly discuss them with the profession in the Central Manpower Committee. The problem with senior registrar posts in this specialty is the shortage of suitable applicants and so the proposal to establish a training cadre of registrar posts should be particularly valuable. We have already invited Regions to ask for additional training posts in mental handicap and the number of posts created and filled has shown an encouraging rise in the last year. Once a solid training base is in being it should not be difficult to establish the 5-10 additional senior registrar posts needed. An association of these training posts and consultant posts with academic and teaching centres should be entirely beneficial.

I hope the Memorandum will go a long way towards clarifying the way forward for this special aspect of psychiatry.

$$
\begin{aligned}
& \text { Elizabeth Shore } \\
& \text { Deputy Chief Medical Officer }
\end{aligned}
$$

